\title{
The Risks and Solutions of Green Financial Management in Application
}

\author{
Li TAO ${ }^{a,{ }^{*}}$, Qing-Jun MENG ${ }^{b}$, Yong-Jun TANG ${ }^{c}$
}

\author{
Business school of Hohai University, Jiangning, Nanjing, Jiangsu Province, China
}

ataoli1495@163.com, bmqj@hhu.edu.cn, 'tangyj508@126.com

*Li TAO

Keywords: Supply-side Reform, SWOT Analysis, Green Financial Management.

\begin{abstract}
To develop low-carbon and recycle economy and solve environmental pollution problems, businesses are now focusing more on the application of Green Financial Management(GFM).There are risks in applying GFM such as large increase of costs, lack of professional knowledge of Green Accounting and not enough talents. The solutions to these potential problems include incentive policies of the government, improvement of Green Accounting skills and cooperations with all sectors of society to foster professional talents. SWOT Analysis is a significant tool in this issue.
\end{abstract}

\section{The Generation of GFM and the Current Situation of Application}

The environmental pollution problems and ecological damage are becoming more severe with the rapid development of economy. In the late 1980s, developed countries started to pay attention to environment problems. In June 1992, Environmental Protection Convention was passed in the United Nations Conference on Environment and Development(Zhang, 1997). Under guiding concepts of Low-carbon Economy, Recycle Economy and Green Management, businesses begin to seek the integration of their profits and environmental protection, which increases the requirement of GFM application.

Synthesis domestic and International scholars' study, GFM can be defined as the following: using Recycle Economy and Sustainable Development as guidance, GFM refers to economy management activities that combine the values of economy, society and environmentin the operations to realize the balance of businesses' development and social development. Under the background of market's focusingmore on the environment, businesses need to build their competitive advantages to get the upper hand by reducing environmental costs, improving the efficiency of using resources and lessen the consumption of energy.

Traditional financial management has a lot of disadvantages. It does not consider the benefits of the environment and social responsibilities of businesses. Also, it cannotmake a comprehensive assesment of management performnce in operation. GFM generated as a tool which haselasticity and flexibility to improve the efficiency and quality of management in the fierce market competition of the environmental protection era (Volberda, 2005). However, businesses' application of GFM has many potential problems because of the lack of policies, imperfection of accounting systems and not having enough professional talents.

\section{Relevant Research}

Most scholars believe that applying GFM is profitable for businesses.According to Hart, Green Management can reduce the operational costsof businesses (Hart, 1997). Molina analyzes the market competition and then points out that businesses’ applying Green Management can increase the entry barriers of thier potential competitors (MolinaAzorin etal, 2009). Xiaohong Yan believes that Green Management meets the requirement of the green customers and also matchesthe long-term development goals of businesses, so it can get more support from the government (Yan, 2001).

Other scholars believe there are problems with applying Green Management.According to Xia Xiao, traditional development mode of economy restricts the application of GFM to some extent (Xiao, 2011). Jianming Wang and Jingang Bao point that applying GFM is bound to increase 
businesses' costs without the support of the government.Besides, it is hard to calculate the enviroemental benefitsthat GFM brings (Wang \& Bao, 2003).

In conclusion, there are arguments about applying GFM. Also, GFM has only researches on theory but no suggestionsabout how to take it into practice. This article is going to use SWOT to analyze the strengthens, weaknesses, opportunities and threats in applying GFM and then try to provide some recommendations on it.

\section{SWOT Analysis and the Application}

SOWT is a tool to analyze competitiveness. In 1971, professor Andrewsproposed this decision-making method in his book: The Concept of CorporateStrategy, to explain the living environment and developing strategy. Businesses face competitiveness both from the internal and the external. Strengths (S) and Weaknesses (W) are internal analyze while Opportunities (O) and Threats (T) are external analyze. SWOT analysis in GFM is shown in Fig. 1.

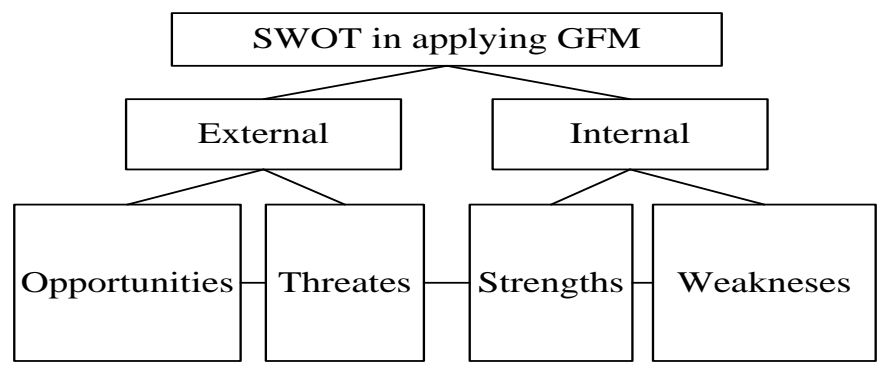

Fig. 1. SWOT in Applying GFM

\section{The External Environment}

\section{The External Opportunities}

\section{The Improvement of the Policies about Environmental Protection}

In recent years, China encourages low-carbon and recyclable economy . The environment management system was made to improve the global environment quality. The EnvironmentalImpact Assessment Law of the People's Republic of China passed in 2016 (Ministry of Environment Protection of the People's Republic of China, 2016). In 2017, the National People's Congress of the People's Republic of China and the Chinese People's Political Consultative Conference concentrate on environmental protection issues. Criterias for protection of the water environment,atmosphere and the management of solid waste and chemical pollution were published, in which the particular standards and requirement of monitoring provide evidence for the application ofGFM. These policies are beneficial for businesses tonormalize and improvetheir operational management.

\section{The Environment Protection Technologies Develop a Lot}

Businesses rely more on energy saving and emission reduction technologies since they prefer to reform from high energyconsumption and pollution model to low carbon and environmental-friendly model. It is essential for businesses to base GFM on advanced technology, professional equipments and intellectuals. Nowadays, the domestic and international have all acquired some achievements in technologies of disposing polluted water, atmosphere, solid waste and radiation pollution. In addition, environmental impacts assessment and pollution emission monitoring technology are also improving at an amazing speed. The update of these technologies provides conditions for applying GFM.

\section{The External Threats}

\section{The Threats Come From Industry Competition}

Businesses need to investa lot for introducing advanced environmental technology, buying equipment and infrastructures and build energy-saving basic facilities, which increases the costs to 
some extents. This may lead to the loss ofcompetitive advantages in production costs and market price. Businessesmay even face the risk of being eliminated from the market. Applying GFM is restricted because of these kinds of potential problems. In addition, since businesses have differences in levels of environmental protection skill and energy-using efficiency,which themselves are parts of the competitive elements, taking GFM into practice is facing the threatsfrom market competition.

\section{Not enough Support from the Government}

Even though there are relevant documents from the environment departments to make criterias for environmental protection, there are gaps in monitoring on the high pollution, energy consumption and emission industries. Also, applying GFM will increase the operational costs while there are no fiscal subsidies or Green Tax policies from the government. The government does not do enough work to support and guide the industries.

\section{The Internal Environment}

\section{The Internal Strengths}

\section{Improvement the Awareness of Social Responsibility and Industry Image}

Even though the economy grows faster and faster in recent years, many businesses do not have a correct opinion about growth. Some manufacturers are not responsible to the society and prefer to solve environmental problems after development. GFM is based on the management values of social man rather than economy man (Guo, 2011). Businesses are treated as commercial organizations with social responsibility. It regards the business as a economic organization that is highly responsible for the environment. It encourages companies to protect the environment while extracting from the natural, thus to maximum the benefits of both economy and environment. Businesses can improve their brand images since the country are now advocating environmental protection.

\section{Changes of Opinions of Employees and Improvement of Management System}

Staffs'lack of environmental awareness and their different views on the environment are likely to cause the businesses'emission and pollution. The application of GFM is a method to promise the healthy, long-term and sustainable development. It can change the attitudes of the employees towards the environment and help build their senses of energy-saving and emission-reduction. As a result, the quality of all the staffs can be improved. Besides, some industries focus only on quantity increase instead of quality improvement.They ignore the construction of management system especially the financial management system. GFM implement can help solve the problems caused by the imperfect management system and follow the trend of green social development.

\section{The Internal Strengths}

\section{Need of Large Amount of Investment}

Since businessess did not not have enough equipment, technologies and talents in the past that are necessary for applying GFM, the basic construction will cost a lot of foundations in the early stage. It needs assets to improve environmental technologies, buy equipment and tools, build energy-saving infrastructures and so on to realize the targets of improving operational processes, reducing resource consumption and lesening pollution, which makes the application of GFM hard to realize. If businesses do not have enough assets resources and financing channels, they may frustrate a lot.

\section{Not popularized Essential Technologies and Information of Accounting Relevanted}

Traditional accounting rules still practicable but they do not cover GFM. China does not have appropriate policies about Green Accounting. Since the accounting standards are now limited in businesses, there is large space for research and development of the identification of economic benefits. Also, there is still a long way to go for businesses to perfectly use the accounting information, thus to exactly make comparison of the GFM profits. 


\section{Need for Specialists}

GFM is a new progress in the financial management field, which is largely different from traditional financial management.Because of the staffs'lack of professional skills, educationand instruction or guidance of GFM, many businesses are now still operating under the traditional financial management system. However, It is hard to apply GFM based on current platform.

\section{Strategies of Applying GFM}

\section{Grab Opportunities and Eliminate Threats}

\section{Follow Up to Policy Moves and Value Cooperating with the Government}

At present, businesses are still having lots of problems with applying GFM. Enhancing the government-enterprise cooperation will help a lot. On the one hand, the government can establish special foundation to encourage businesses to transform their management mode. Financial subsidies should be provided for businesses who apply Green Management actively. On the other hand, to fill in gaps in assets, the government can make credit support policies or provide interest subsidies, which aims at guiding banks to lend to green businesses with favorable conditions. As for businesses themselves, grabbing chances offered by the government is the very first task. Make sure the energy is fully used and emissions are up to the standard, then they can easily get enough finance resources.

\section{Improve Technological Level to Enhance Competitive Advantages and Cooperate with the Government}

Technology holds a central position in businesses' green reformation. To apply GFM, it is essential to enhance core competitiveness by innovating energy saving and emission reduction technology. By participating in international conferences or establishing industry society associations, businesses can learn up-dated theory achievements, study technologies on green reformation and share advanced experience. Then, there will be reasonable and efficient solutions, which can help businesses generate less wastes, reduce emissions and weaken dangers brought by pullutions. Raising technology level can not only cut down subsequent inputs thus to increase advantages in costs, but also enhance green businesses’ core competitiveness.

\section{Enlarge Strengths and Avoid Weaknesses}

\section{Introduce and Train Talents, Then Build the GFM System}

Applying GFM needs professional talents to provide intellectual support. First, combining with their own characteristics, businesses can enhance the training of their staffs with theoretical knowledge and practical skills, thus to cultivate professional talents who know his business very well. Second, talents can be introduced from the outside, such as graduates from colleges of finance and accounting, staffs of accounting firms and high-leveled labors from foreign countries. In addition, using international advanced experience, businesses can build Green Accounting criterions and evaluation systems, which will help to accurately measure the costs and benefits.

\section{Strengthen Cooperation with All Social Sectors to Expand Financing Channels}

To apply GFM, businesses need large quantities of money, which will not be enough without cooperations with the government, financing institutions and other social sectors. Firt, businesses can apply for green financial fund. Besides, under the help of preferential policies which require banks to lend with favorable conditions, businesses can easily get a loan. Furthermore, businesses themselves can raise money lying idle in society by issuing stocks and bonds. Sincere cooperation from all walks of life can not only help businesses solve money problems, but also supervise if they truly implement GFM into practice. 


\section{Conclusion}

In china, the development of GFM is still at the threshold. During its application process, opportunities and challenges exist side by side. There are lots of risks terribly hindering its development, such as lack of support from the government, specialized knowledge and talents and the imperfection of accounting system. Businesses are full of worries about if to apply GFM.

The China government is now advocating the construction of Green environment protection career. At the $27^{\text {th }}$ conference of Deepen the reform Group, Jinping Xi pointed that: Green development is an important mission of supply-side structural reform, good ecological environment is an important measure (Xi, 2016). Businesses should follow up to policy moves in time. With supports of the government, the financial world and other social sectors, businesses can well-probably achieve a win-win result between economic benefits and environment benefits by applying GFM.

\section{Acknowledgement}

This research was supported by the National Social Science Planning Fundation: Project-Study of Balance Sheet of Natural Resources Based on River Basin Ecosystem Management(20155020811) .

\section{References}

[1] Meilin Zhang. Pilot study of Green Financial Management[J]. Journal of Shanghai University,1997,(02):15-18.(In Chinese)

[2] Henk Volberda. Create a flexible enterprise-How to keep competitive advantages[M]. Beijing: Posts and Telecom Press,2005:1-14.

[3]Hart SL. Beyond greening:Strategies for a sustainable world[J].Harvard Business Review,1997:66-76.

[4] Molina Azorin J F,Claver Cortes E,Lopez Gamero M D,etal. Green management and finincial performance:a literature review[J].Management Decision,2009:1080-1100.

[5] Xiaohong Yan. Analysis of Green Financial Management[J]. Productivity Reserch,2001,(04):54-56+129.(In Chinese)

[6] Xia Xiao. Problems and Resolutions about businesses' Green Financial Management in our country[J]. Academic Forum,2011,(12):119-123.(In Chinese)

[7] Jianming Wang, Jingang Bao. Discussion about Green Financial Managemet[J]. Journal of Nanjing University of Technology,2003,(03):72-76.(In Chinese)

[8] China's Ministry of Environmental Protection. Law of Environment Impact Assesment of the People’s Republic of China[EB/OL].http://www.zhb.gov.cn/,2016-09-27.(In Chinese)

[9] Haifang Guo. Explosion of Green Financial Management[J]. Reserch of Finance and Accounting,2011,(03):43-45.(In Chinese)

[10] Jinping Xi. Good ecological environment is an important measure of the supply-side structural reform[N]. The Xinhua News Agency, 2016-04-28(A05).(In Chinese) 